\title{
Financing Developing Country Debt: A Sovereign Borrowing Entity Proposal
}

\author{
David J. Moore ${ }^{1}$, Roger W. Clark ${ }^{2}$, George C. Philippatos ${ }^{3}$ \\ ${ }^{1}$ College of Business, Administration, California State University, Sacramento, USA \\ ${ }^{2}$ School of Business, Austin Peay State University, Clarksville, USA \\ ${ }^{3}$ Department of Finance, University of Tennessee, Knoxville, USA \\ Email: ${ }^{*}$ djmphd@csus.edu
}

Received 16 July 2014; revised 11 August 2014; accepted 21 August 2014

Copyright (C) 2014 by authors and Scientific Research Publishing Inc.

This work is licensed under the Creative Commons Attribution International License (CC BY).

http://creativecommons.org/licenses/by/4.0/

c) (i) Open Access

\section{Abstract}

This paper proposes the creation of a Sovereign Borrowing Entity (SBE) under the auspices of the International Monetary Fund (IMF) and other International Financial Institutions (IFIs). The SBE guarantees bond issuances by developing nations, packages them in relatively small denominations, and auctions them to the public. Should a developing debtor country fail to pay its debt, the SBE would raise funds through a punitive tariff on all exports administered by the IMF member nations. We develop a theoretical model of the proposed Sovereign Borrowing Entity (SBE) and provide viability evidence using export and debt data from the World Bank. It is our hope that this paper will encourage further dialogue and research on financing developing country debt in a more effective manner.

\section{Keywords}

Sovereign, Debt, Default, Restructuring, IMF

\section{Introduction}

The financial arrangements of the current sovereign debt issuance system are similar to financing in the nineteenth century. Loans are made on general credit, and creditors do not have full access to the debtor's books, and in many cases creditors have no real control over how the money is spent or how it is repaid. The remedy for default is the sovereign equivalent of debtor's prison; that is, the drying up of trade credits, restrictions on trade with the debtor country, and lawsuits like the ongoing (as of June 2014) suit against Argentina by U.S. hedge funds Gramercy Funds Management LLC and Elliott Management Corp (the last holdouts from

*Corresponding author.

How to cite this paper: Moore, D.J., Clark, R.W., \& Philippatos, G.C. (2014). Financing Developing Country Debt: A Sovereign Borrowing Entity Proposal. Journal of Financial Risk Management, 3, 67-77. 
Argentina's 2002 default). To the chagrin of the global financial system, these sanctions and lawsuits have not aided debtor nations in paying off their debts. Starting around 2004, Great Britain agreed to pay off $10 \%$ of the debt of developing countries, but this does not remedy the underlying problem of their growing needs for outside capital.

This paper proposes a new type of sovereign bond issuance where risk is largely determined at the time of issuance and greater transparency is given to the purchasers. The International Monetary Fund will create and fund a sovereign borrowing entity (SBE) that is similar to Sallie Mae in the United States. The IMF would examine the debt capacity of countries interested in offering bonds on the market using methodologies similar to those used by Moody's or Standard and Poor's. An acceptable price would be established commensurate with the risks involved. The SBE would then package the issuance in relative small denominations $(\$ 50,000$ to $\$ 500,000$ US) in a manner similar to the Sallie Mae bonds in the United States and sell them at auction on a regular basis. The SBE will guarantee the bonds at a specific interest rate.

Should a nation fail to pay when due, the agency would have the power to levy a tariff on the exports of the debtor country. This will give the agency enforcement capabilities through its member nations. In addition, the debtor nation will make its books available to the SBE and funds will be released only as the projects, for example, roads or schools, are completed. This arrangement should open the markets for developing country bonds to a worldwide group of investors. Since there will be no one nation heavily invested in the debtor country (diversification effect), the temptation to restrict trade will be minimal. Instead, a tariff can be better tailored to collect revenues with minimal effects on the debtor country's external trade.

In the remaining pages we provide some background on developing country soverign debt, highlight problems with current approaches to default resolution, discuss similarities between Sallie Mae and the proposed SBE, provide a theoretical model of the proposed SBE, and then turn to debt statistics from The World Bank to assess the proposed SBE necessity and viability.

\section{National vs. Corporate Debt}

Bulow (2002) likened debt of developing countries to corporate junk bonds, the main differences being collateral and control. Corporate bonds generally have the assets of the firm for backing. Further, should a corporation have poor governance, the trustee in bankruptcy has the option to completely replace the management team. Neither of these two options is operationally feasible with national debt. The markets also rate the debt of developing countries at junk-bond levels, viewing them as more than likely to default. As such,generally a $50 \%$ writedown is anticipated over the next decade (Bulow, 2002).

A further problem exists in the size of the total national debt and its uses. While it has been observed that in general the total national debt of a developing country amounts to only three to six months of its GDP, this is deceiving. Sachs (2002) develops this concept further with his "poverty trap". He notes the large number of small developing countries (SDC's) in a continual state of financial crisis for many years and that the only ones "cured" of high debt were the countries with larger initial gross domestic incomes (GDI's). Sachs infers that, in contrast to the neo-Classical view, savings and capital accumulation rates are non linear. Low income countries will be spending more on basic survival rather than the building of capital. As a consequence, these small countries are unlikely to lift themselves out of poverty. Also the lending patternsof multinational agencies such as the IMF and the World Bank are prone to use arbitrary formulas for lending (and lending only enough to avert disaster, rather than solve the basic problem). Sachs proposes that debt renegotiations take into consideration the fact that maximization of debt repayments is only one of a series of objectives. Other objectives are: a) giving the insolvent country a fresh start; b) preserving its public functions; and c) achieving its development objectives. This calls for comprehensive plans by the creditor countries and International Financial Institutions (IFI's) to foster development and for pulling developing countries out of the poverty trap.

All of the above literature, however, begs the question of why a nation would bother paying its debts. The age of gunboat diplomacy, where a powerful nation's fleet could sail into the harbor of a defaulting debtor nation and seize its assets, is past. Also, most developing nations do not have assets of high value outside of their borders subject to seizure. Still, nations that renounce their debt entirely are few or almost non-existent. Nations in financial trouble usually undergo financial reorganization under the auspices of the IMF and renegotiation of debt under the Paris and London Clubs. Again, why would they go to this trouble if they can simply renounce their debt? 
Eaton \& Gersovitz (1981) advance the "Reputational Capital” model. In their framework the loss of future borrowing power is greater than the amount of debt renounced. However, this is questioned by Bulow \& Rogoff (1989) who argue that loss of reputational capital alone cannot account for the full value of the debt renounced. Rogoff \& Zettelmeyer (2002) note the literature of the 80's does not give easy solutions. It would appear the true economic loss is both loss of reputation and the possibility that individual lawsuits against a nation would trigger cross-default clauses in all contracts of the country. This would entail a "rush to the courthouse" by all creditors and imperil ongoing IMF loans.

Another cost of default would be the drying up of trade credits for both imports and exports (Cohen, 1991; Kaletsky, 1985; Rogoff, 1999). This could effectively cut off the debtor's trade with the outside world and bankrupt merchants in the debtor country that could depend on this trade. Also, Rose (2005) notes a country's problems with portfolio creditors may have an adverse impact on foreign trade. In his paper Rose notes that a typical debtor country's outside trade shrank on average $8 \%$ a year and the effects lasted for fifteen years after renegotiation of debt under the Paris club. One unexplored question was whether this was a punishment by the creditor countries for defaulting or a natural consequence of poor economic conditions in the debtor countries.

Rose \& Spiegel (2004) find a high correlation between the amount of loans a creditor country makes to a debtor country and amount of trade with the debtor country. This seems to add weight to the hypothesis that trade can be used as a lever to obtain favorable terms by the creditor. Should this be the case, it would appear the market for government bonds of developing countries is limited to the trading partners of the debtor country. Potential creditors (e.g. for example portfolio investors) in other countries may not have the power to enforce payment under present arrangements.

\section{Renegotiating National Debt}

When a nation finds itself unable to make timely payments on its debt it must first go to the IMF to obtain temporary financial relief and submit to a program approved by the IMF for resolving the underlying problem. Once the country has agreed to the IMF program it petitions the "Paris Club" to renegotiate its sovereign debt. The Paris Club is an (ad hoc) informal organization of nations that work to reschedule loan repayments on terms the debtor nation can afford to pay. It can lengthen the terms and/or change the interest rates, depending on the needs of the nation. This club has no formal enforcement powers and works by consensus. The process usually takes six to eight months. Afterwards, the debtor nation goes to the London club to work out its private loans. In general, the London Club reschedules loans using the same terms as the Paris Club. This arrangement has generated some criticism. Typically, the criticism is that the IMF has a "one size fits all" policy that does not take into full consideration the specific problems in each country (Stiglitz, 2002a). Also, the mere existence of supra national organizations may create a "moral hazard" problem. Additionally, the fact that the Paris Club operates by consensus without enforcement authority may create a "free rider" problem (supra). Finally, the entire process of negotiation engenders serious problems with informational asymmetries and adverse selection.

The presence of such informational asymmetries may affect asset values through a nexus of economic distortions that manifest themselves as "agency costs", "signaling costs", "moral hazard costs", "free rider costs", and "adverse selection costs", among others. In general the presence and costs of informational asymmetries are higher in the mixed market economies of the developing (debtor) nations than they are in the market economies of the G8 (creditor) countries. Much of the problem can be traced to lax accounting standards, poor record keeping, and internal auditors controlled by those being audited (Johnson, 1992).

Should a country have a healthy, corruption free system it will find its official statistics not much different from a corrupt country that also misrepresents its own statistics. Here there is a problem with informational asymmetry and adverse selection. It is to the creditors' interest to have as much information as possible concerning a nation's ability to repay its debts. However, as Stiglitz (1975, 2002b) suggests, it is not in the creditor's interest to have this information made public knowledge, so that he/she can take advantage of this informational asymmetry to demand higher interest rates. All of this, of course, leads to the problem of adverse selection. Creditors, without the benefit of credible public regulatory agencies that promote and enforce full disclosure, will be forced to rely on private, often unreliable, channels of information. This will force interest rates up to offset perceived debtor risk. Debtor nations will, in turn, only borrow if they have high positive NPV projects or when they have no intention of repaying the full amount of the debt. As a consequence of this, debt from developing countries has consistently stayed at junk bond levels (Bulow 2002). 
Informational asymmetry also arises in the prospect of a nation having its debt repurchased by larger industrial countries. The problem here is that the entire premise of this debt repurchase rests on the value of the debt remaining at the market before the repurchase is announced. When it is discovered the debt will be repurchased by the larger industrial nations, the debt value will rise to approximate the value of the larger countries bonds (Bulow \& Rogoff, 1990).

One possible solution to the informational asymmetry proplem may be in the syndicated loan market. Sufi, (2007) finds informational asymmetry is greatest with companies new to the loan market. Here due diligence and monitoring are most needed. Lead bankers that arrange the loans usually overcome this fear of informational asymmetry by taking a large position in the loan amount. The reputation of the lead lenders may mitigate, but not reduce significantly, the effects of informational asymmetry.

Dailami et al. (2008) offer additional support of informational asymmetry mitigation through the syndicated loan market. Using data from J P Morgan "Emerging Market Bond Index Plus" (EMBI+) spreads, Dailami et al. study the secondary markets of Brady Bonds and Eurodollar issues for all major sovereign borrowers (17 countries). The authorsseperate public data into "crisis" and "non-crisis" periods for countries that are close to the "borderline of solvency" and those that are not. The authors conclude as follows, "... there is evidence that investors are much more able to discriminate among borrowers, and less likely to infer that problems in one country signal problems in others...” They further offer clinical evidence that the Argentinean debt default in 2002, the largest known default in recent history, did not cause much disruption in world capital markets, nor did its neighboring countries suffer major increases in their spreads.

\subsection{Moral Hazard}

Moral hazard suggests insurance against some unforeseen event may actually encourage it to occur. As applied to multinational finance, the IMF has arranged standby "funding packages" for several emerging-market countries in financial crisis. This could have long-term adverse effects on the world economy. For creditors, the presence of standby financing encourages lending to poor countries without fully factoring the importance of financial risk. Thus, some debtor countries may obtain financing without undertaking needed economic reforms.

Another case of moral hazard exists when we witness the private creditors egging the IFIs on to bail out the bankrupt debtor countries. Bulow (2002) states that although we ...” know that it would be better, from an efficiency standpoint, ..." IFIs could precommit not to bail out the countries in distress. Bulow further states the IFIs ...” are probably making loans that earn zero economic profits. Therefore the IFIs facilitate excessive lending" and "Therefore the cost to the IFIs must be greater than or equal to the inefficiencies created." Indeed, in many cases, the IFIs make loans that are below the break even point.

There is empirical evidence of the presence and extent of moral hazard in sovereign debt financing. Kamin (2004) studies moral hazard using the spreads before the 1995 Mexican bailout as a benchmark. This was the first major bailout of a large country in financial trouble and, he reasons, before this, countries would have no reasonable expectations of a major bailout in the event of a financial crisis. Kamin finds no statistically significant increase in the spreads before and after the Mexican bailout except in the period of 1996 through mid 1998, which he attributes to "financial market exuberance". Thus, Kaminconcludes that there is little evidence for moral hazard.

Dell'Ariccia, Schnabel, \& Zettelmeyer (2006) discover possible evidence of moral hazard in the aftermath of the Russian lending crisis of 1998 . Here the authors regress the spreads of sovereign bonds against country fundamentals both before and after the Russian crisis. Dell'Ariccia et al. find spreads increase significantly after the crisis when it was perceived that country bailouts were not going to be as common as in the past. Further, these spreads were largest in emerging market countries. Dell'Ariccia et al. point out, however, that this evidence for moral hazard rests on the premise that country bailouts do not significantly reduce true economic risk. Therefore the insurance against default, at a minimum, does not correct the underylying cause of default (economic risk).

\subsection{The Free Rider Problem}

Sachs (1986) outlined the "free rider" problem of renegotiating debt in the current environment. When a country defaults on debt involving several creditors it is to a creditor's advantage to hold out in any renegotiations, rather than join in with the rest of the creditors. In this way the creditor may sue to enforce their legal rights and obtain 
a better settlement than other creditors. For example, as of June 2014, Gramercy Funds Management LLC and Elliott Management Corp, two U.S. hedge funds, are still holding out after 13 years in hopes of maximizing collection of outstanding debt from Argentina. This can cause a destructive race to force a debtor to pay through the courts. Balanced against this is the problem of jurisdiction. The fact is, lawsuits are brought in a country other than the debtor country. Unless the debt is secured by collateral located in another country the debtor nation can simply refuse to pay.

\subsection{Off Balance Sheet Financing and SBEs}

The Special Purpose Entity (SPE) has acquired a rather questionable reputation with the Enron and World Com scandals. Much of this is undeserved. The SPE was originally conceived as a method of allowing private firms to avoid capitalization of certain types of leases under Financial Accounting Standard (FAS) 13. Under the original SPE rules outside investors would contribute at least 3\% (now 10\%) of a company's capital while the originator company could guarantee as much as $90 \%$ of the SPE's debt. In many cases this allowed the SPE to obtain lower financing rates than the originator company's normal borrowing rate. Additionally, the SPE had the cosmetic effect of keeping the liabilities associated with the project off the originator company's books .

The SPE is still used broadly in private industry and in some cases in governmental entities. In the United States the Federal National Mortgage Association (Fannie Mae) and the Governmental National Mortgage Association (Ginnie Mae), among others, function as SPE's. In addition Japan has formed offshore SPE's to handle non-performing loans and enhance the income statements and balance sheets of their commercial banks. The international financial institutions (IFI's) such as the World Bank or the IMF also function as a form of SPE for the United Nations and the world community. They generally couch their aid to developing countries in the form of loans or loan guarantees. This allows the developed countries to utilize leverage in aiding less developed countries. As an example, the World Bank is capitalized at $\$ 189.5$ billion while only $\$ 11.5$ billion has been paid in by the subscribing countries (Bulow, 2002).

\subsection{Similarities of U.S. SPEs and the Proposed Soverign Borrowing Entity}

The most well known United States Governmental SPEs are Ginnie Mae (GNMA), Freddie Mac (FRE), Fannie Mae (FNMA) and Sallie Mae (SLM). All four are institutions founded by the U.S. Government. These SPEs provide liquidity for the housing and student loan markets and also rate, grade, securitize, and frequently auction underlying claims (mortgages and/or loans).

The main focus of Ginnie Mae is to ensure liquidity for U.S. Government insured mortgages, including those insured by the Federal Housing Administration (FHA), the Veterans Administration (VA), and the Rural Housing Administration (RHA). The majority of mortgages securitized as Ginnie Mae Mortgage-Backed Securities (MBSs) are those guaranteed by the FHA. FHA mortgagees are typically first time home buyers and low income borrowers. Sallie Mae, on the other hand, guarantees the timely payment of interest and principal for college education (student) loans, while Fannie Mae resembles a hybrid of Sallie Mae and Ginnie Mae.

Table 1 summarizes the attributes of the proposed sovereign borrowing entity (SBE) and Sallie Mae, which most closely resembles the proposed SBE.The primary operational difference lies in the handling of default. The proposed SBE recovers debt payments in the event of default through punitive tariffs. This is quite similar to a proposed change in student loan administration proposed in Reich (2010). Reich suggests that students loan

Table 1. Similarities between sallie mae and proposed sovereign borrowing entity.

\begin{tabular}{|c|c|}
\hline Sallie Mae (SLM) & Proposed Sovereign Borrowing Entity (SBE) \\
\hline $\begin{array}{l}\text { Rates, grades, securitizes, } \\
\text { and auctions loans of college students }\end{array}$ & Rates, grades, securitizes, and auctions loans of less developed countries \\
\hline $\begin{array}{l}\text { Funds are released as academic work progresses } \\
\text { (e.g., on a semester basis). }\end{array}$ & Funds will be released as projects progress (on a quarterly basis). \\
\hline $\begin{array}{l}\text { Loan repayments are typically made. Student borrowers } \\
\text { will repay old loans by taking new loans (refinancing). }\end{array}$ & $\begin{array}{l}\text { Loans typically will not be paid off; rather they will be replaced with new loans. } \\
\text { This will allow more interest to be earned (from refinancing). }\end{array}$ \\
\hline $\begin{array}{l}\text { Default is mitigated by a screening (monitoring) } \\
\text { process and the refinancing of loans. }\end{array}$ & $\begin{array}{l}\text { Default will be mitigated by a screening/monitoring process (rating, grading, } \\
\text { and frequent auctioning) and application of punitive tariffs in the event of default. }\end{array}$ \\
\hline
\end{tabular}


should be tied to subsequent income as opposed to a fixed payment schedule. Similarly, in the event of default the propsed SBE will tie loan repayments to exports of the debtor country.

\section{Soverign Borrowing Entity and Repayment Choice}

Let us assume there is one country, $\alpha$, that wishes to borrow money. It may choose to borrow directly from a creditor country, $\mu$, or borrow through the SBE. Should $\alpha$ borrow through $\mu$ and finance it with the issuance of sovereign bonds, it will face the penalty of trade restrictions in the event of default. Rose (2005) and Rose \& Spiegel (2004) demonstratetrade restrictions are used in such circumstances. Trade restrictions do not seem particularly effective as the punishment hurts the creditor in trade as well as the debtor, without actually remedying the default. Apparently the market does not think highly of this as a remedy given the trading of these obligations at junk bond levels.

Should the country choose to go through the SBE, it will receive a loan amount of $L_{\alpha}$ from the SBE. We begin with a two-period model in which $L_{\alpha}$ is received in period one and repaid in period two at

$$
D=\left(1+R_{\alpha}\right) L_{\alpha}
$$

where $R_{\alpha}$ is the debtor country's cost of capital. Loan proceeds will be used to enhance trade with other countries. This will foster diversification of trading partners and give the debtor country revenues in the second period of $\Psi T_{\alpha}$ where $T_{\alpha}$ is the total amount of exports from the debtor country and $\Psi$ is the percentage of total exports retained by the debtor country. It is further assumed the prices of the exports are inelastic. The utility function in country $\alpha$ satisfies the following condition:

$$
E_{1}\left(U_{\alpha}\right)=U\left(C_{\alpha 1}\right)+\beta E\left(U\left(C_{\alpha 2}\right)\right)
$$

where $U^{\prime}>0, U^{\prime \prime}<0, C_{\alpha t}$ represents the consumption of country $\alpha$ in period $t(t=1,2)$, and $\beta=1 /\left(1+R_{\alpha}\right)$ represents the debtor's discount rate (Rose \& Spiegel, 2004).

Consumption in period one is:

$$
C_{\alpha 1}=Y_{\alpha 1}+L_{\alpha}
$$

where $Y_{\alpha 1}$ is the debtor country income and $L_{\alpha}$ is the country's sovereign liabilities. Payment of the debt as agreed in period two yields second period consumption equal to:

$$
C_{\alpha 2}=Y_{\alpha 2}+\Psi T_{\alpha}-D
$$

where $D=\left(1+R_{\alpha}\right) L_{\alpha}$ represents the repayment of debt. If the debtor country decides to default it is no longer faced with penalties of trade restrictions. In the event of default second period consumption is:

$$
C_{\alpha 2}^{*}=Y_{\alpha 2}+\Psi T_{\alpha}-\Delta
$$

where $\Delta=\left(1+R_{\theta}\right) L_{\alpha}$ represents the loss of foreign trade, $R_{\theta}>R_{\alpha}$, and $R_{\theta}$ represents the new discount rate of the country in default, adjusted for costs of reputational capital and loss of foreign trade. From Equations (3) and (4) it is evident the utility maximizing choice of the debtor country will be to pay its debts under all circumstances.If the debtor country is unable to repay debt punitive tariffs shall be imposed by all member countries to ensure debt is repaid. To clarify the mechanics of the punitive tarifffs we rewrite Equation (4):

$$
C_{\alpha 2}^{*}=Y_{\alpha 2}+\Psi^{*} T_{\alpha}
$$

where $\Psi^{*}=\Psi-\left(1+R_{\theta}\right) L_{\alpha} / T_{\alpha}$ Equation (5) illustrates the imposition of punitive tariffs in the event of default reduces the debtor country's share of total export revenue $\left(\Psi^{\wedge *}<\Psi\right)$ while simultaneously repaying debt with penalty interest $\left(R_{\theta}>R_{\alpha}\right)$. Again, these punitive tariffs are administered by all IMF member nations that are trading partners and participate in the proposed SBE. As such we have a mechanism of collective discipline as opposed to a bilateral stalemate (e.g., the ongoing Argentine obligations to the remaining two U.S. hedge fund holdouts). The repayment (performing) and non-repayment (default) scenarios are depicted in Figure 1.

\section{Data and Observations}

\subsection{Data}

All data are obtained from The World Bank International Debt Statistics (IDS) database. Table 2 summarizes 

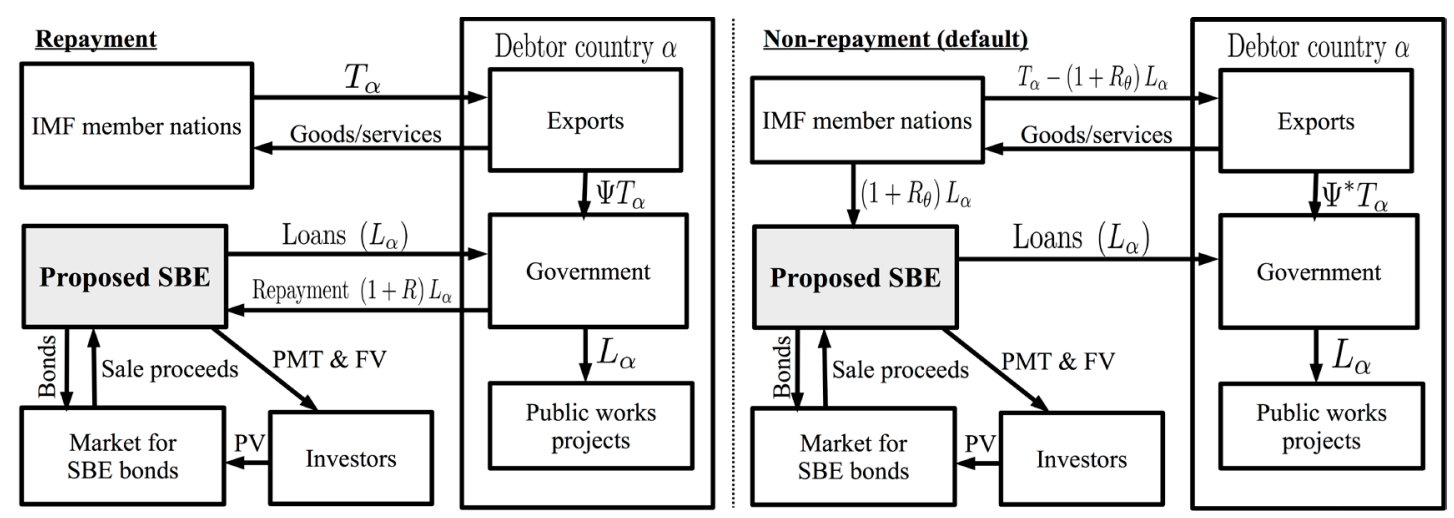

Figure 1. Graphical illustration of proposed SBE model.

Table 2. Variable names and descriptions.

\begin{tabular}{|c|c|c|}
\hline Variable & IDS name & Description/calculation \\
\hline Exports & BX.GSR.TOTL.CD & Goods and services exports \\
\hline Debt & DT.DOD.DPPG.CD & Public and publicly guaranteed (PPG) long term debt \\
\hline IntArr & DT.IXA.DPPG.CD & PPG interest in arrears \\
\hline PrinArr & DT.AXA.DPPG.CD & PPG principal in arrears \\
\hline ArrTotal & & PPG payments in arrears (total): IntArr + PrinArr \\
\hline$\Delta$ IntArr & DT.IXA.DPPG.CD & Change in PPG interest in arrears: $\operatorname{IntArr}_{t}-\operatorname{IntArr}_{\{t-1\}}$ \\
\hline$\Delta$ PrinArr & & Change of PPG principal in arrears: PrinArr $t=\operatorname{PrinArr}_{\{t-1\}}$ \\
\hline$\Delta$ ArrTotal & & Change of PPG payments in arrears (total): $\Delta$ IntArr $+\Delta$ PrinArr \\
\hline IntPay & DT.INT.DPPG.CD & Actual PPG interest payments \\
\hline PrinPay & DT.AMT.DPPG.CD & Actual PPG principal payments \\
\hline PMTActual & & Actual PPG payment (total): IntPay + PrinPay \\
\hline $\mathrm{N}$ & DT.MAT.DPPG & Average maturity of newly issued debt \\
\hline $\mathrm{R}_{\alpha}$ & DT.INR.DPPG & Interest rate on newly issued debt \\
\hline $\mathrm{R}_{\theta}$ & & Penalty interest rate in the event of default: $\mathrm{R}_{\theta}=\mathrm{R}_{\alpha}+0.02$ \\
\hline Arr2Debt & & ArrTotal/Debt \\
\hline$\Delta$ Arr2Debt & & $\Delta$ ArrTotal/Debt \\
\hline PMTActual2Debt & & PMTActual/Debt \\
\hline Arr2Exports & & ArrTotal/Exports \\
\hline$\Delta$ Arr2Exports & & $\Delta$ ArrTotal/Exports \\
\hline Debt2Exports & & Debt/Exports \\
\hline
\end{tabular}

the variable names, corresponding names in the IDS database, and includes a brief description.The sample window used in this study is from 1982 to 2012 and includes all variables listed in Table 2.

Table 3 presents the data for IDS classification “All developing countries" (country code "LMY”) which is the subset of low or middle income countries. Data are expressed in billions of current U.S. dollars as recorded in the IDS database.

Table 3 reveals defaults occur sporadically. From 1982 to 1995 arrears (ArrTotal) increases monotonically while the remaining years has a fairly random mixture of increases and decreases.To abstract from inflation, and to assess SBE necessity and, viability, we compute several ratios described Table 4. We use the maximum of 
Table 3. IDS All Developing Countries data (billions of current U.S. dollars).

\begin{tabular}{|c|c|c|c|c|c|c|c|c|c|c|c|c|c|c|}
\hline Year & xports & Debt & IntArr & PrinArr & ArrTotal & $\Delta$ IntArr & $\Delta$ PrinArr & $\Delta$ ArrTotal & IntPay & PrinPay & PMT & $\mathrm{N}$ & $\mathrm{R} \alpha$ & $\mathrm{R} \theta$ \\
\hline 1982 & 377 & 415 & 4.01 & 5.80 & 81 & 1.21 & 231 & 3.52 & 31.37 & 30.96 & 62.33 & 15.2 & $10.05 \%$ & $12.05 \%$ \\
\hline 1983 & 373 & 484 & 5.60 & 7.21 & 2.82 & 1.59 & 41 & 3.00 & 31.83 & 30.20 & 2.03 & 14.7 & $8.70 \%$ & $10.70 \%$ \\
\hline 1984 & 404 & 19 & 8.42 & 13.59 & 22.01 & .81 & 38 & 9.19 & 35.27 & 32.04 & 67.31 & 16.3 & $8.63 \%$ & $10.63 \%$ \\
\hline 1985 & 391 & 599 & 10.05 & 18.49 & 28.54 & 1.63 & 1 & 6.53 & 38.25 & 38.05 & 76.30 & 16.4 & $7.43 \%$ & $9.43 \%$ \\
\hline 1986 & 346 & 703 & 9.02 & 24.90 & 33.92 & -1.03 & 6.40 & 5.38 & 37.59 & 40.59 & 78.17 & 17.8 & $6.48 \%$ & $8.48 \%$ \\
\hline 987 & 409 & 830 & 15.41 & 28.99 & 44.40 & 6.39 & 400 & 1040 & 39.22 & 42.02 & 81.24 & 18.1 & $6.17 \%$ & $8.17 \%$ \\
\hline 1988 & 459 & 844 & 18.35 & 38.33 & 56.69 & 2.94 & 9.34 & 2.29 & 47.26 & 52.11 & 99.37 & 16.8 & $6.43 \%$ & $8.43 \%$ \\
\hline 1989 & 508 & 90 & 29.58 & 43.47 & 73.05 & 11.22 & 5.13 & 16.36 & 42.62 & 51.61 & 94.23 & 17.7 & $6.55 \%$ & $8.55 \%$ \\
\hline 1990 & 588 & 32 & 40.22 & 54.00 & .22 & 10.64 & 0.53 & $1.1 /$ & 41.93 & 57.62 & 99.55 & 18.0 & $6.69 \%$ & $8.69 \%$ \\
\hline 1991 & 613 & 958 & 42.96 & 58.58 & 101.54 & 2.74 & 4.58 & 7.32 & 41.45 & 54.45 & 95.90 & 17.9 & $6.24 \%$ & $8.24 \%$ \\
\hline 1992 & 679 & 68 & 40.00 & 67.37 & 107.37 & -2.96 & 8.79 & 5.83 & 42.14 & 64.56 & 106.69 & 16.9 & $.92 \%$ & $7.92 \%$ \\
\hline 1993 & 734 & 1020 & 42.84 & 73.16 & 116.01 & 2.84 & 5.79 & 8.64 & 39.21 & 63.53 & 102.74 & 15.7 & $5.56 \%$ & $7.56 \%$ \\
\hline 1994 & 865 & 1110 & 38.89 & 77.33 & 116.23 & -3.95 & 4.17 & 2 & 52 & 7 & 11 & 16.5 & $\%$ & $7.44 \%$ \\
\hline 1995 & 1040 & 1170 & 38.71 & 82.25 & 120.96 & -0.18 & 4.92 & 4.74 & 54.78 & 83.21 & 137.99 & 14.0 & $.10 \%$ & $8.10 \%$ \\
\hline 1996 & 1160 & 1160 & 32.02 & 74.86 & 106.88 & -6.69 & -7.39 & -14.08 & 55.11 & 106.00 & 161.11 & 13.4 & $6.33 \%$ & $8.33 \%$ \\
\hline 1997 & 1 & 1140 & 2 & 67.45 & & -4.19 & -7.41 & -11.60 & & & & 14.9 & & $8.32 \%$ \\
\hline 1998 & 1220 & 1200 & 31.83 & 76.99 & 108.82 & 4.00 & 9.53 & 13.53 & 54.21 & 91.74 & 145.95 & 13.3 & $6.12 \%$ & $8.12 \%$ \\
\hline 1999 & 1290 & 1210 & 33.46 & 73.32 & 106.78 & 1.63 & -3.67 & -2.0 & 56.30 & 98.04 & 33 & 14.2 & $6.49 \%$ & $8.49 \%$ \\
\hline 2000 & 1540 & 1180 & 27.34 & 53.51 & 8 & -6.12 & -19.81 & -25.93 & & 0 & 59 & 14.5 & $\%$ & $8.94 \%$ \\
\hline 2001 & 1510 & 1170 & 29.15 & 53.58 & 82.74 & 1.81 & 0.07 & 1.89 & 55.13 & 104.00 & 15 & 15.9 & $\%$ & $7.53 \%$ \\
\hline 2002 & 1630 & 1240 & 31.37 & 54.65 & 86.02 & ר2 2 & 106 & 320 & 48.99 & 112.00 & 160.99 & 16.6 & $4.92 \%$ & $6.92 \%$ \\
\hline 2003 & 1940 & 1290 & 42.69 & 72.80 & 115.48 & 11.31 & 18.15 & 29.46 & 50.40 & 133.00 & 183.40 & 14.9 & $4.66 \%$ & $6.66 \%$ \\
\hline 2004 & 2460 & 1340 & 47.88 & 82.81 & 130.69 & & 10.01 & 15.20 & 49.43 & 118.00 & 167.43 & 17.0 & $4.24 \%$ & $6.24 \%$ \\
\hline 2005 & 2900 & 1230 & 20.01 & 44.53 & & & & -00.04 & & & 179.91 & 17.3 & & $6.88 \%$ \\
\hline 2006 & 3530 & 1100 & 25.54 & 44.71 & זר ת & 0 & (1) & 21 & 51.57 & 155.00 & 206.57 & 18.1 & $4.90 \%$ & $6.90 \%$ \\
\hline 2007 & 4320 & 1270 & 27.25 & 46.44 & 7260 & 171 & 173 & 340 & 56.37 & 115.00 & 171.37 & 19.8 & $4.84 \%$ & $6.84 \%$ \\
\hline 2008 & 5180 & 1320 & 27.05 & 47.95 & 75.00 & -0.21 & 1.51 & 1.31 & 54.49 & 129.00 & 183.49 & 18.3 & $4.17 \%$ & $6.17 \%$ \\
\hline 2009 & 4240 & 1410 & 26.28 & 49.92 & 76.20 & -0.77 & 1.97 & 1.20 & 50.35 & 108.00 & 158.35 & 18.1 & $3.36 \%$ & $5.36 \%$ \\
\hline 2010 & 5290 & 1530 & 21.57 & 39.98 & 61.54 & -4.71 & -9.94 & -14.65 & 50.23 & 105.00 & 155.23 & 24.4 & $3.18 \%$ & $5.18 \%$ \\
\hline 2011 & 6400 & 1610 & 18.58 & 41.13 & 59.71 & -2.99 & 1.15 & -1.83 & 2 & 0 & 181 & 21.1 & $\%$ & $5.26 \%$ \\
\hline 2012 & 6720 & 770 & 0.33 & 44.40 & 73 & 1.75 & 3.27 & 5.02 & 80.98 & 101.00 & 181.98 & 21.0 & $2.85 \%$ & $4.85 \%$ \\
\hline
\end{tabular}

Table 4. Ratio names, description, and calculation.

\begin{tabular}{ccc}
\hline Name & Description & Calculation \\
\hline Arr2Debt & Arrears (total) to debt & ArrTotal/Debt \\
$\Delta$ Arr2Debt & Change in arrears (total) to debt & Pax[IntArr, 0] + max[PrinArr, 0])/Debt \\
PMTActual2Debt & Actual payments to debt & ArrTotal/Exports \\
Arr2Exports & Arrears (total) to exports & (max [IntArr, 0] + max [PrinArr, 0])/Exports \\
$\Delta$ Arr2Exports & Change in arrears (total) to exports & Debt/Exports \\
Debt2Exports & Debt to exports &
\end{tabular}


interest or principal arrears and zero in the numerator of $\Delta$ Arr2Debt and $\Delta \operatorname{Arr} 2$ Exports as opposed to simply $\Delta$ ArrTotal. This is done because $\Delta$ ArrTotal captures net changes in arrears (e.g., 5.83B in 1992) while the max [] function isolates new payments in arrears (e.g., 8.79B in 1992).

\subsection{Observations}

Table 5 presents the time series of ratios described in Table 4. Several observations are of note:

Table 5. Time series of ratio values.

\begin{tabular}{|c|c|c|c|c|c|c|}
\hline Year & Arr2Debt & $\Delta$ Arr2Debt & PMTActual2Debt & Arr2Exports & $\Delta$ Arr2Exports & Debt2Exports \\
\hline 1982 & 0.0237 & 0.0085 & 0.1502 & 0.0260 & 0.0093 & 1.1008 \\
\hline 1983 & 0.0265 & 0.0062 & 0.1282 & 0.0344 & 0.0080 & 1.2976 \\
\hline 1984 & 0.0424 & 0.0177 & 0.1297 & 0.0545 & 0.0227 & 1.2847 \\
\hline 1985 & 0.0476 & 0.0109 & 0.1274 & 0.0730 & 0.0167 & 1.5320 \\
\hline 1986 & 0.0482 & 0.0091 & 0.1112 & 0.0980 & 0.0185 & 2.0318 \\
\hline 1987 & 0.0535 & 0.0126 & 0.0979 & 0.1086 & 0.0256 & 2.0293 \\
\hline 1988 & 0.0672 & 0.0146 & 0.1177 & 0.1235 & 0.0268 & 1.8388 \\
\hline 1989 & 0.0821 & 0.0184 & 0.1059 & 0.1438 & 0.0322 & 1.7520 \\
\hline 1990 & 0.1011 & 0.0227 & 0.1068 & 0.1602 & 0.0360 & 1.5850 \\
\hline 1991 & 0.1060 & 0.0076 & 0.1001 & 0.1656 & 0.0119 & 1.5628 \\
\hline 1992 & 0.1109 & 0.0091 & 0.1102 & 0.1581 & 0.0129 & 1.4256 \\
\hline 1993 & 0.1137 & 0.0085 & 0.1007 & 0.1580 & 0.0118 & 1.3896 \\
\hline 1994 & 0.1047 & 0.0038 & 0.1037 & 0.1344 & 0.0048 & 1.2832 \\
\hline 1995 & 0.1034 & 0.0042 & 0.1179 & 0.1163 & 0.0047 & 1.1250 \\
\hline 1996 & 0.0921 & 0.0000 & 0.1389 & 0.0921 & 0.0000 & 1.0000 \\
\hline 1997 & 0.0836 & 0.0000 & 0.1423 & 0.0750 & 0.0000 & 0.8976 \\
\hline 1998 & 0.0907 & 0.0113 & 0.1216 & 0.0892 & 0.0111 & 0.9836 \\
\hline 1999 & 0.0882 & 0.0013 & 0.1275 & 0.0828 & 0.0013 & 0.9380 \\
\hline 2000 & 0.0685 & 0.0000 & 0.1386 & 0.0525 & 0.0000 & 0.7662 \\
\hline 2001 & 0.0707 & 0.0016 & 0.1360 & 0.0548 & 0.0012 & 0.7748 \\
\hline 2002 & 0.0694 & 0.0026 & 0.1298 & 0.0528 & 0.0020 & 0.7607 \\
\hline 2003 & 0.0895 & 0.0228 & 0.1422 & 0.0595 & 0.0152 & 0.6649 \\
\hline 2004 & 0.0975 & 0.0113 & 0.1250 & 0.0531 & 0.0062 & 0.5447 \\
\hline 2005 & 0.0569 & 0.0000 & 0.1463 & 0.0242 & 0.0000 & 0.4241 \\
\hline 2006 & 0.0590 & 0.0002 & 0.1736 & 0.0199 & 0.0001 & 0.3371 \\
\hline 2007 & 0.0580 & 0.0027 & 0.1349 & 0.0171 & 0.0008 & 0.2940 \\
\hline 2008 & 0.0568 & 0.0011 & 0.1390 & 0.0145 & 0.0003 & 0.2548 \\
\hline 2009 & 0.0540 & 0.0014 & 0.1123 & 0.0180 & 0.0005 & 0.3325 \\
\hline 2010 & 0.0402 & 0.0000 & 0.1015 & 0.0116 & 0.0000 & 0.2892 \\
\hline 2011 & 0.0371 & 0.0007 & 0.1128 & 0.0093 & 0.0002 & 0.2516 \\
\hline 2012 & 0.0366 & 0.0028 & 0.1028 & 0.0096 & 0.0007 & 0.2634 \\
\hline
\end{tabular}




\section{Observation 1. Defaults still occur but have declined recently.}

The percentage of debt in arrears (Arr2Debt) declined from 11.09\% in 1992 to 3.66\% in 2012. In addition, the ratio of arrears to exports (Arr2Exports) also declined from 15.81\% in 1992 to just $0.96 \%$ in 2012. Unfortunately, both Arr2Debt and Arr2Exports were lower in the past. If history does follow the tendency to repeat we can presume additional defaults (arrears) are in the future.The proposed SBE is one mechanism that can aid in resolving those future defaults.

Observation 2. Debt has declined relative to exports.

Total debt relative to exports declined nearly monotonically from its peak of 2.03 in 1986 to 0.26 in 2012 . This is good news for the proposed SBE in that the pool of tariff-able funds (exports) that may called on in the event of default is increasing relative to the amount of default-able funds (debt).

Observation 3. A small tariff may be sufficient.

The latest Arr2Exports value of $0.96 \%$ is promising as it represents a relatively small tariff that could be applied to recoup all payments in arrears as of 2012. However, this low tariff is no guarantee of future performance given the lower value of $0.80 \%$ in 1983 that subsequently increased to a peak of $16.56 \%$ in 1991 . In addition, the sample average for Arr2Exports is $7.39 \%$. Clearly a peak $16.56 \%$ tariff (or even the sample average $7.39 \%$ ) is extermely burdensome and perhaps crippling. This suggests that earlier intervention, i.e. implementation of the SBE, could help mitigate the accumulation of arrears.

\section{Conclusion}

Soverign defaults still occur (arrears are nonzero) and lawsuits to recover from defaulted debt are ongoing (e.g., U.S. hedge funds vs. Argentina 2014). Our theoretical model and brief analysis of World Bank International Debt Statistics data suggest the proposed Soverign Borrowing Entity could be used to finance developing country debt. The theoretical model illustrates the utility maximizing choice is to repay. However, willingness to repay is distinct from ability to repay. The analysis of IDS data reveals defaults can and still occur, albeit at a lower amount relative to both total debt and exports in the later years of the sample. Regarding exports, the amount of tariff-able funds (exports) relative to default-able balances (debt) has increased substantially from 1986 to 2012. This is good news for the proposed SBE in that the pool of funds that may called on in the event of default is increasing relative to the amount of outstanding debt. It is our hope that this paper will encourage further dialogue and research on financing developing country debt in a more effective manner.

\section{Acknowledgements}

An earlier version of this research was presented at the Cambridge Business and Economics Conference, July 2013, Cambridge, UK. We wish to thank participants of the Cambridge conference, Andrey Mikhailitchenko of California State University Sacramento, and Kojo Yelpaala of the University of the Pacific for their helpful comments.

\section{References}

Bulow, J. (2002). First World Governments and Third World Debt. Brookings Papers on Economic Activity, 1, $229-255$. http://dx.doi.org/10.1353/eca.2002.0004

Bulow, J., \& Rogoff, K. (1989). Sovereign Debt: Is to Forgive to Forget? The American Economic Review, 79, 43-50.

Bulow, J., \& Rogoff, K. (1990). Cleaning up Third World Debt without Getting Taken to the Cleaners. The Journal of Economic Perspectives, 4, 31-42. http://dx.doi.org/10.1257/jep.4.1.31

Cohen, D. (1991). Private Lending to Sovereign States: A Theoretical Autopsy. Cambridge, MA: MIT Press.

Dailami, M., Masson, P. R., \& Padou, J. J. (2008). Global Monetary Conditions versus Country-Specific Factors in the Determination of Emerging Market Debt Spreads. Journal of International Money and Finance, 27, 1325-1336. http://dx.doi.org/10.1016/j.jimonfin.2008.07.003

Dell’Ariccia, G., Schnabel, I., \& Zettelmeyer, J. (2006). How Do Official Bailouts Affect the Risk of Investing in Emerging Markets? Journal of Money, Credit and Banking, 38, 1689-1714. http://dx.doi.org/10.1353/mcb.2006.0091

Eaton, J., \& Gersovitz, M. (1981). Debt with Potential Repudiation: Theoretical and Empirical Analysis. The Review of Economic Studies, 48, 289-309. http://dx.doi.org/10.2307/2296886

Johnson, D. M. (1992). Professionalism in the Third World. Internal Auditor, 49, 51. 
Kaletsky, A. (1985). The Costs of Default. East Longmeadow, MA: Priority Press.

Kamin, S. B. (2004). Identifying the Role of Moral Hazard in International Financial Markets. International Finance, 7, 2559. http://dx.doi.org/10.1111/j.1367-0271.2004.00128.x

Reich, R. B. (2010). Aftershock: The Next Economy and America's Future. New York: Random House LLC.

Rogoff, K. (1999). International Institutions for Reducing Global Financial Instability. The Journal of Economic Perspectives, 13, 21-42. http://dx.doi.org/10.1257/jep.13.4.21

Rogoff, K., \& Zettelmeyer, J. (2002). Bankruptcy Procedures for Sovereigns: A History of Ideas, 1976-2001. IMF Staff Papers, 470-507.

Rose, A. K. (2005). One Reason Countries Pay Their Debts: Renegotiation and International Trade. Journal of Development Economics, 77, 189-206. http://dx.doi.org/10.1016/j.jdeveco.2004.03.006

Rose, A. K., \& Spiegel, M. M. (2004). A Gravity Model of Sovereign Lending: Trade, Default, and Credit. IMF Staff Papers, 50-63.

Sachs, J. (2002). Resolving the Debt Crisis of Low-Income Countries. Brookings Papers on Economic Activity, 257-286. http://dx.doi.org/10.1353/eca.2002.0013

Sachs, J., \& Williamson, J. (1986). Managing the LDC Debt Crisis. Brookings Papers on Economic Activity, 1986, 397-440. http://dx.doi.org/10.2307/2534478

Stiglitz, J. E. (1975). The Theory of Screening, Education, and the Distribution of Income. American Economic Review, 65, 283-300.

Stiglitz, J. E. (2002a). Globalism’s Discontents. American Prospect, A16-A21.

Stiglitz, J. E. (2002b). Information and the Change in the Paradigm in Economics. American Economic Review, 92, $460-501$. http://dx.doi.org/10.1257/00028280260136363

Sufi, A. (2007). Information Asymmetry and Financing Arrangements: Evidence from Syndicated Loans. The Journal of Finance, 62, 629-668. http://dx.doi.org/10.1111/j.1540-6261.2007.01219.x 
Scientific Research Publishing (SCIRP) is one of the largest Open Access journal publishers. It is currently publishing more than 200 open access, online, peer-reviewed journals covering a wide range of academic disciplines. SCIRP serves the worldwide academic communities and contributes to the progress and application of science with its publication.

Other selected journals from SCIRP are listed as below. Submit your manuscript to us via either submit@scirp.org or Online Submission Portal.
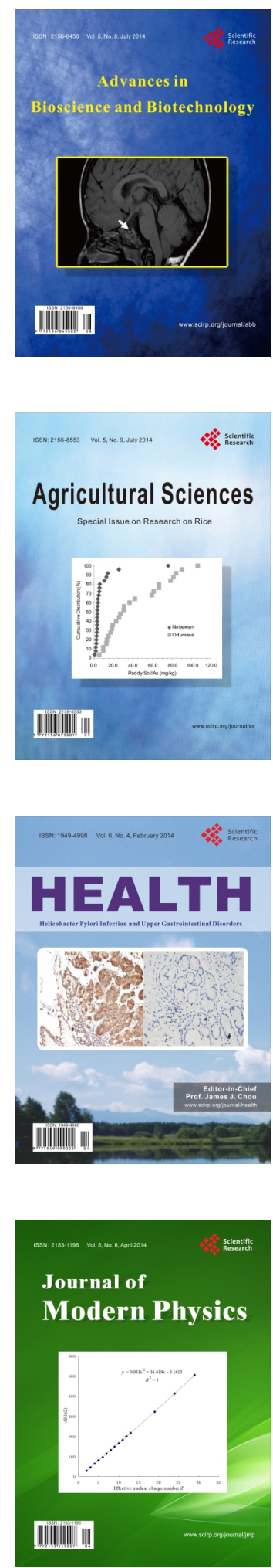
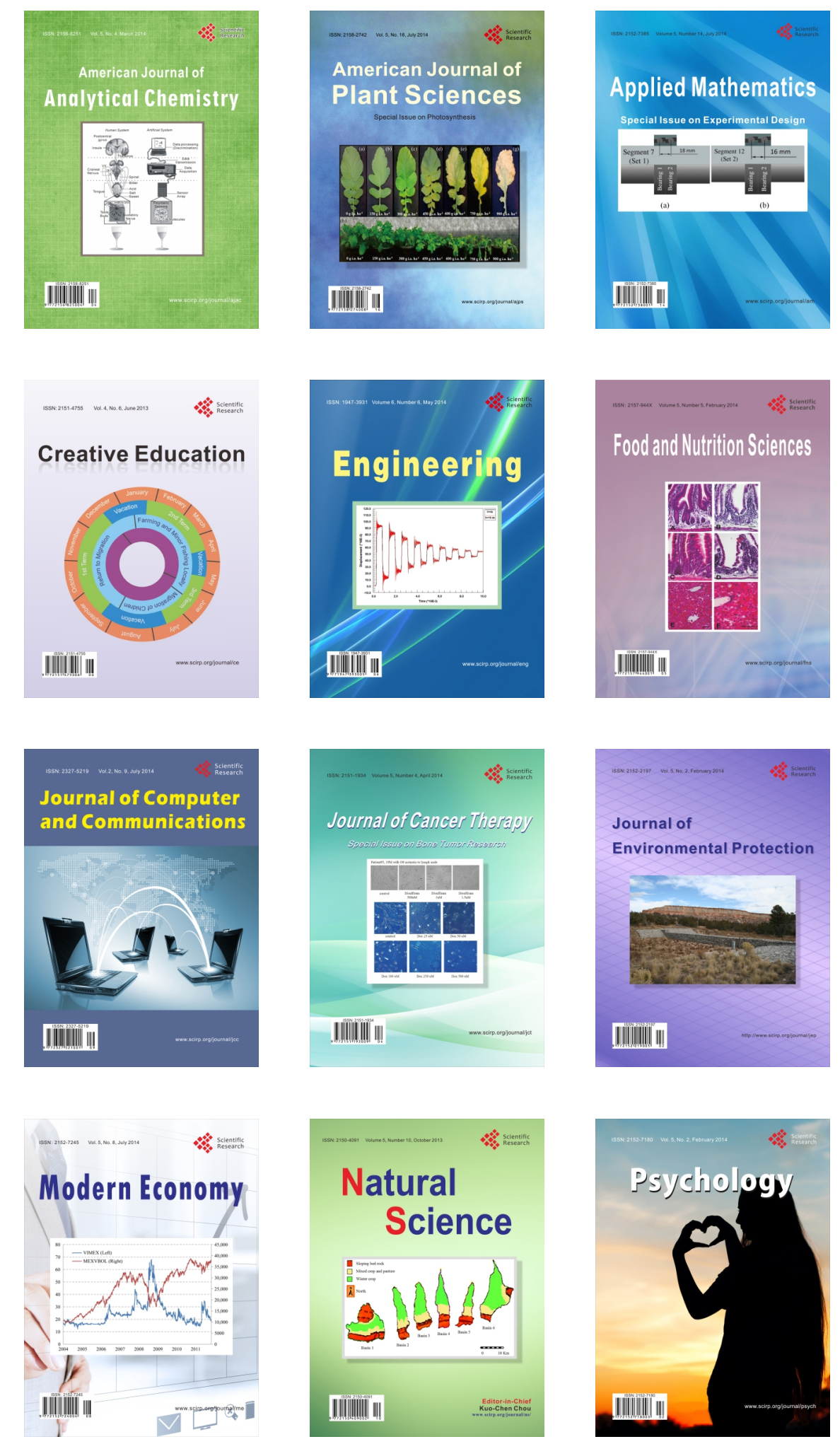